Nature

Article original

\title{
Morpho - physiological characteristics of Cover crops for analysis of upland rice production in relay intercropping systems
}

\author{
René K. Akanvou ${ }^{1 *}$, Mathias Becker ${ }^{2}$, Lammert Bastiaans ${ }^{3} \&$ Martin J. KropfF $^{3}$ \\ ${ }^{1}$ Centre National de Recherche Agronomique 10 B.P. 13 Abidjan, Côte d'Ivoire \\ ${ }^{2}$ Institute of Agricultural Chemistry (ACl), University of Bonn, Kralrobert-kreiten-str, 13, 53127 Bonn, Germany \\ ${ }^{3}$ Wageningen University, P.O. Box 430, 6700 AK Wageningen, The Netherlands \\ *Author to whom correspondence should be addressed (Email : reneakanvou@yahoo.fr) \\ Reçu le 19-06-2006, accepté le 14-05-2007.
}

\begin{abstract}
To assess the suitability of Leguminous species in rice intercropping systems, physiological and morphological characteristics of Crotalaria juncea, Cajanus cajan, Mucuna pruriens var. cochinchinensis, Calopogonium mucunoides, Aeschynomene histrix and Stylosanthes hamata were determined in monoculture. C. cajan and S. hamata were selected and intercropped with two upland rice cultivars (WAB56-50, WAB450-24-3-2-P18-HB syn. V4) with different competitive ability, at sowing dates ranging from 0 to 84 days after rice sowing (DARS). In monoculture, $C$. juncea and $C$. cajan produced nearly 9 ton dry matter ha-1 ${ }^{-1}$, whereas the other species produced below half this amount. Total $\mathrm{N}$ in leaf materials varied between $25 \mathrm{~kg}$ and $70 \mathrm{~kg} \mathrm{ha}^{-1}$. Based on relative growth rate of the leaves, the height increase rate and total biomass, $C$. juncea, $C$. cajan and $M$. pruriens were identified as potentially most competitive. In intercropping system, a logistic function was adequate to describe rice grain yield, final rice biomass and legume biomass at one week after rice harvest as a function of legume sowing dates. Differences in rice grain yield were significant $(P<0.001)$ due to strong competition effect between 0 and 28 DARS. The yield loss - legume biomass relationship showed that $C$. cajan was the most appropriate legume species in relay intercropping system with upland rice.
\end{abstract}

Keys words : competition, intercropping, nitrogen, Oryza, yield loss

\section{Résumé}

Caractéristiques morpho physiologiques des plantes de couverture pour l'analyse de la production du riz de plateau dans les systèmes de culture relais

Pour déterminer les légumineuses appropriées dans les systèmes d'association avec le riz, des caractéristiques morphologiques et physiologiques de Crotalaria juncea, Cajanus cajan, Mucuna pruriens var. cochinchinensis, Calopogonium mucunoides, Aeschynomene histrix et Stylosanthes hamata ont été déterminées en monoculture. C. cajan et S. hamata ont été sélectionnées et semées en association avec deux variétés de riz de plateau (WAB5650, WAB450-24-3-2-P18-HB syn. V4) de compétitivité différente, à des dates de semis variant entre 0 et 84 jours après le semis du riz (DARS). En monoculture, $\mathrm{C}$. juncea et $\mathrm{C}$. cajan ont produit près de 9 tonnes de matières sèches ha${ }^{1}$, tandis que les autres espèces ont produit moins de la moitié de cette quantité. L'azote $(N)$ totale dans les feuilles, varie entre $25 \mathrm{~kg} \mathrm{ha}^{-1}$ et $70 \mathrm{~kg} \mathrm{ha}^{-1}$. Sur la base de la croissance relative des feuilles, du taux de croissance en hauteur et de la biomasse totale, C. juncea, C. cajan et M. pruriens ont été identifiées comme potentiellement les plus compétitives. En association, une fonction logistique était adéquate pour expliquer le rendement grain du riz, la biomasse totale du riz et la biomasse des légumineuses une semaine après la récolte du riz en fonction des dates de semis des légumineuses. Les différences de rendement en grain du riz étaient significatives $(P<0.001)$ à cause de la forte compétition observée entre 0 et 28 DARS. La relation perte de rendement - biomasse des légumineuses, montre que C. cajan est la légumineuse la plus appropriée dans un système de culture relais avec le riz de plateau. Mots clés : compétition, associations, azote, Oryza, perte de rendement 


\section{Introduction}

In West Africa, upland rice (Oryza sp.) ecosystems represent about $60 \%$ of the rice growing area (Terry et al., 1995). Average grain yield of $1.0 \mathrm{t} \mathrm{ha}^{-1}$ is low compared to the world average yield of $1.5 \mathrm{t} \mathrm{ha}^{-1}$. In Côte d'Ivoire, yield gap analysis in three agro-ecological zones showed that weeds, nitrogen and to some extent drought were the major factors limiting rice productivity (Becker \& Johnson, 1998). As nitrogen $(\mathrm{N})$ is the most deficient nutrient in upland soils in West Africa, biologically fixed nitrogen $(\mathrm{N})$, and released during residue decomposition of leguminous species can help meet the $\mathrm{N}$ demand of subsequent crops. The main factors determining the suitability of leguminous species for the build up of soil fertility depends on species characteristics and the cropping systems. Leguminous cover crops can be introduced in cropping systems either as a component of a rotation system or through intercropping. In intercropping systems, competition between species will occur. Therefore, apart from productivity and nitrogen fixing ability, competitive ability becomes another obvious characteristic determining the suitability of a leguminous species as an intercrop. Poorly competing species will produce fewer biomass and will not play an important role in the maintenance of soil fertility. Consequently, the success of intercropping crops and cover crops is largely determined by the selection of the most appropriate species and additionally by the design of an optimal management strategy for the intercrop.

To minimize competition between species, growth retardants have been proposed to reduce growth of the associated legumes in maize (Mulongoy \& Akobundo, 1990). Shifting the relative sowing dates of the various intercropped components is yet another means to ensure a better use of available resources and to minimize yield loss of the main crop (Midmore, 1993). Thus, to facilitate the selection of the most appropriate legume for the development of rice-legume intercropping systems for short fallow improvement, detailed knowledge on growth and morphological charac-teristics is required (Morris et al., 1990; Becker \& Johnson, 1998). Morphological growth characteristics such as early relative growth rate of leaf area and earliness of height development have been identified to determine competition in intercropping systems (Kropff \& van Laar, 1993). For rice, in addition to the above parameters, maximum height (Bastiaans et al., 1997), specific leaf area (SLA), tillering ability and duration of the crop (Dingkuhn et al., 1999) have been reported as other important factors.

In this study, characteristics indicating competitive ability of cover crops species will be determined and used for analysing rice productivity and legume biomass production in relay intercropping systems.

\section{Materials and methods}

The study was conducted between 1997 and 1999 cropping seasons at the Africa Rice Center (WARDA) main research station at Bouaké, Côte d'Ivoire. Cumu-lative annual rainfall was on average $1000 \mathrm{~mm}$. The experimental site is located in the derived savanna zone characterised by a soil type classified as alfisol according to the USDA soil classification system. Land was ploughed and fertilized with $30 \mathrm{~kg} \mathrm{P}$ (triple super phosphate) and $34 \mathrm{~kg} \mathrm{~K}(\mathrm{KCl})$ at field preparation. To determine growth characteristics and competitive ability of the legumes, six species were selected based on a previous adaptability screening trial (Becker \& Johnson, 1998). The selected legumes comprised two creeping species: Mucuna pruriens var. cochinchinensis and Calopogonium mucunoides, two semi-erect shrubby-type species Stylosanthes hamata and Aeschynomene histrix, and two woody erectgrowing species Cajanus cajan and Crotalaria juncea. Legume seeds were sown manually. Seeds of $S$. hamata and A. histrix were pre-treated for two hours in concentrated solution of sulphuric acid, mixed with fine white sand and dibbleseeded at 80 hills per $\mathrm{m}^{2}(12.5 \times 10 \mathrm{~cm})$. Three weeks after emergence, seedlings were thinned to two plants per hill, resulting in 160 plants $\mathrm{m}^{-2}$. The other four species were dry-dibble-seeded using three seeds per hole at 20 hills per $\mathrm{m}^{2}$ (25 $\times 20 \mathrm{~cm}$ ). Two weeks after sowing, C. cajan and $C$. juncea were thinned back to two plants per hill (40 plants $\mathrm{m}^{-2}$ ), whereas $M$. pruriens and $C$. mucunoides were thinned to one plant per hill (20 plants $\mathrm{m}^{-2}$ ).

For intercropping studies, two rice cultivars were intercropped with two cover crops using an 
additive experi-mental design. Rice cultivars comprised the improved japonica WAB56-50 and the interspecific hybrid WAB450-24-3-2-P18-HB also called V4. The two leguminous cover crop species were the erect fast growing Cajanus cajan and the semi-erect slow-growing forage legume Stylosanthes hamata. Each legume species was sown at four different dates after sowing of the rice crop (DARS). The experiment was laid out in a randomized complete block design with three replicates and three factor combinations. The factors consisted of two rice cultivars, two cover crop species and four dates of legume introduction into the standing rice crop. In addition to mixture plots, monoculture plots of rice (one sowing date) and of legumes (4 sowing dates corresponding to the dates of legume introduction in intercropping) were established resulting in a total of 26 treatments. In the first year, the relative sowing dates of the legumes were 0 (D1), 28 (D2), 56 (D3), 84 (D4) days after rice sowing (DARS) for the introduction of the two legume species. In the second year, legume sowing dates were modified based on the results of the first year: (1) after 56 DARS, rice yield was hardly affected by legume establishment, and (2) during the first four weeks, both rice yield and legume biomass were extremely sensitive to the period of legume introduction. Therefore, D1 to D4 were set respectively at $0,14,28$, and 56 DARS. Individual plots measured $6 \mathrm{~m} \times 4 \mathrm{~m}$ including 3 $\mathrm{m}^{2}(3 \mathrm{~m} \times 1 \mathrm{~m})$ area for non-destructive measurements and final harvest. Rice was dibble-seeded at $0.25 \mathrm{~m} \times 0.20 \mathrm{~m}$ and thinned to three seedlings per hill after three weeks, resulting in 60 plants per $\mathrm{m}^{2}$. At each sowing date, 12 plots ( 2 rices $\times 2$ legumes $\times 3$ replicates) were intercropped by sowing legumes between rows of rice. C. cajan was seeded in single rows between rice rows at $0.25 \mathrm{~m} \times 0.20 \mathrm{~m}$ with two seeds per hill (40 plants $\mathrm{m}^{-2}$ ) whereas $S$. hamata was seeded in double rows. Rows were $12.5 \mathrm{~cm}$ apart and planting distance in the row was 10 $\mathrm{cm}$. Three weeks after sowing, plants were thinned to 2 plants per hills (160 plants $\mathrm{m}^{-2}$ ). Legumes in monoculture were sown at the same density using the same spatial arrangement as in mixture. Weeds were removed manually if required.

Measurements on legumes started 3 weeks after sowing. Every two weeks height was measured in the field. Two areas of $0.50 \times 0.40 \mathrm{~m}\left(0.40 \mathrm{~m}^{2}\right)$ were sampled per plot for destructive measurement of leaf area and total biomass until final harvest. Leaves were separated from the stem and leaf area was determined using a LiCor LI-3000 (Lincoln, Nebraska). Dry weight of leaves and stems was determined after oven-dried at $70{ }^{\circ} \mathrm{C}$ for 48 hours. $\mathrm{N}$ content in the foliage was monthly determined by chemical analysis using a standard colorimetric method (Anderson \& Ingram, 1993). Final legume biomass was measured one week after rice harvest.

Dry matter accumulation over time was described using a logistic equation :

$$
Y\left(T S_{s}\right)=Y_{\text {max }} /\left(1+B_{w} \times \exp \left(-R_{w} \times T S_{s}\right)\right)
$$

Where $Y\left(T S_{s}\right)$ is the shoot dry weight at time $T S_{s}$; $Y_{\max }\left(\mathrm{g} \mathrm{m}^{-2}\right)$ is the maximum shoot biomass, $B_{\mathrm{w}}(-$ ) a coefficient describing the shape of the logistic function and $R_{\mathrm{w}}\left({ }^{\circ} \mathrm{Cd}\right)^{-1}$ the relative weight increase. For a better comparison between years, time was expressed as the accumulated degreedays since sowing $\left(T S_{s} ;{ }^{\circ} \mathrm{Cd}\right)$, using a base temperature of $8^{\circ} \mathrm{C}$. For equation (1), the inflection point $M_{w}\left({ }^{\circ} \mathrm{Cd}\right)$ is defined as $\ln \left(B_{w}\right) / R_{w}$. The first derivative of equation (1) was used to derive the growth rate in the inflection point $\mathrm{M}$, which for the logistic function is by definition the maximum growth rate $C_{\mathrm{m}}\left(\mathrm{g} \mathrm{m}^{-2}\left({ }^{\circ} \mathrm{Cd}\right)^{-1}\right)$ :

$$
C_{\mathrm{m}}=Y_{\max } \times R_{\mathrm{w}} / 4
$$

Mean comparisons for dry matter production were determined by ANOVA, using the Genstat statistical package (Genstat, 1998).

Observations on early leaf area development $(L A \mid<1)$ were fitted using an exponential function against temperature sum after emergence :

$\operatorname{LAl}\left(T S_{\mathrm{e}}\right)=\operatorname{LAl}(0) \times \exp .\left(R G R L \times T S_{\mathrm{e}}\right)$

Where $\operatorname{LAI}(0)\left(\mathrm{m}^{2} \mathrm{~m}^{-2}\right)$ is the leaf area index at emergence, $R G R L\left(\left({ }^{\circ} \mathrm{Cd}\right)^{-1}\right)$ is the relative growth rate of leaf area and $T S_{\mathrm{e}}\left({ }^{\circ} \mathrm{Cd}\right)$ refers to the accumulated temperature sum after emergence. A relationship between morphological and physiological parameters was used to differentiate the legume species.

For rice, grain yield and yield components (spikelet number, panicle number and 1000grain weight) were determined from the $3 \mathrm{~m}^{2}$ 
harvest area. Spikelet number was determined on 10 randomly harvested panicles. Harvest index was calculated as a ratio of grain yield over total biomass.

Rice grain yield $\left(Y_{r}(\mathrm{t}) ; \mathrm{kg} \mathrm{ha}^{-1}\right)$ at harvest and legume shoot biomass $\left(\mathrm{Y}_{1}(\mathrm{t}) ; \mathrm{kg} \mathrm{ha}^{-1}\right)$ one week after rice harvest were fitted to a logistic function identical to equation (1), using the relative sowing time of the legume ( $t$; DARS) as an explanatory variable :

$$
Y_{\mathrm{r}}(t)=\frac{Y_{\mathrm{r}, \max }}{1+b_{\mathrm{r}} \exp ^{-c_{\mathrm{r}} t}}
$$

and

$$
Y_{1}(t)=\frac{Y_{1, \max }}{1+b_{1} \exp ^{-c_{1} t}}
$$

$Y_{\max }$ represents the maximum produced biomass $\left(\mathrm{kg} \mathrm{ha}^{-1}\right)$, and $b(-)$ and $c\left(\mathrm{~d}^{-1}\right)$ are parameters describing the logistic equation. For rice, the maximum produced biomass at harvest was set to the value obtained in monoculture, and consequently only the parameters $b$ and $c$ were estimated. The logistic functions were plotted against the relative sowing dates of the cover crop and compared with observed data to assess model performance.

Evaluation of the rice and cover crop competition model

Competition models were derived by combining the monoculture models of rice with the monoculture models of the cover crops. Thus, the rice-legume combinations $(Y$, and $Y$, respectively; $\mathrm{kg} \mathrm{ha}^{-1}$ ) were fitted against relative sowing date of the cover crop ( $t$; days after rice sowing) using the non-linear regres-sion option of Genstat. Equation (2), describing the relation between legume biomass and relative introduction time of the cover crop, was then rewritten to :

$$
t=-\frac{\ln \left(\frac{Y_{1, \max } / Y_{1}(t)-1}{b_{1}}\right)}{c_{1}}
$$

and introduced in equation (1):

$$
Y_{\mathrm{r}}(t)=\frac{Y_{\mathrm{r}, \max }}{1+b_{\mathrm{r}} \exp ^{-c_{\mathrm{r}} t}}=\frac{Y_{\mathrm{r}, \max }}{1+b_{\mathrm{r}} \exp \left(c_{\mathrm{r}}\left(\ln \left(\left(Y_{1, \text { max }} / Y_{1}(t)-1\right) / b_{1}\right) / c_{1}\right)\right)}
$$

This could then be rewritten to obtain a relation between rice yield loss (YLr) and legume biomass:

$$
Y L_{\mathrm{r}}=1-\frac{Y_{\mathrm{r}}(t)}{Y_{\mathrm{r}, \max }}=1-\left(\frac{1}{1+b_{\mathrm{r}} \exp \left(c_{\mathrm{r}}\left(\ln \left(\left(Y_{1, \max } / Y_{1}(t)-1\right) / b_{1}\right) / c_{1}\right)\right)}\right)
$$

\section{Results}

\subsection{Growth characteristics and competitive ability of the legumes}

The initial relative growth rate $R_{\mathrm{w}}\left[\left({ }^{\circ} \mathrm{Cd}\right)^{-1}\right]$ differed among species (Table 1 ). In both years, $M$. pruriens was found to have the highest $R_{w}$, whereas the lowest values were observed for $\stackrel{A}{A}$. histrix and $C$. cajan. Growth duration is reflected in $M_{w}$, the moment to reach $50 \%$ of the maximum obtainable biomass. $M_{w}$ of $M$. pruriens was estimated at around $727^{\circ} \mathrm{Cd}$, indicating the short growth duration of this species. For $C$. juncea, $C$. mucunoides and $S$. hamata, an average value of around $1000{ }^{\circ} \mathrm{Cd}$ was observed. For C. cajan, a slightly higher $M_{\mathrm{w}}$-value, close to $1200{ }^{\circ} \mathrm{Cd}$ was found and the highest values in both years were observed for $A$. histrix with an average of $1500^{\circ} \mathrm{Cd}$. The maximum growth rate $\left(C_{\text {mw }}\right)$ was least for $S$. hamata and $A$. histrix $\left(0.58\right.$ and $\left.{ }^{-w} 0.41 \mathrm{~g} \mathrm{~m}^{-2}\left({ }^{\circ} \mathrm{Cd}\right)^{-1}\right)$, intermediate for $C$. cajan, $M$. pruriens and $C$. mucunoides $\left(0.74,0.7\right.$ and $0.65 \mathrm{~g} \mathrm{~m}^{-2}\left({ }^{\circ} \mathrm{Cd}\right)^{-1}$, respectively) and highest for $C$. juncea $\left(1.13 \mathrm{~g} \mathrm{~m}^{-2}\right.$ $\left({ }^{\circ} \mathrm{Cd}\right)^{-1}$; Table 1). 
Table 1 : Parameters values for the logistic growth equation $Y(T S s)=Y \max /(1+B w \times \exp (-R w \times T S s))$ describing dry matter production and growth rate of the six legumes, and the mean $\mathrm{N}$ accumulation by the species for both years

\begin{tabular}{|c|c|c|c|c|c|c|}
\hline & C. cajan & C. juncea & M. pruriens & C. mucunoides & S. hamata & A. histrix \\
\hline \multicolumn{7}{|l|}{1997} \\
\hline$Y_{\max }\left(g^{-2}\right)$ & 815.2 & 867.8 & 375 & 434.2 & 267.5 & 423.2 \\
\hline Std error & 89.8 & 77.1 & 12.9 & 40.6 & 12.6 & 64.2 \\
\hline $\mathrm{R}_{\mathrm{w}}\left({ }^{\circ} \mathrm{Cd}\right)^{-1}$ & 0.0034 & 0.0053 & 0.0073 & 0.0048 & 0.0061 & 0.0024 \\
\hline Std error & 0.001 & 0.0014 & 0.0016 & 0.0018 & 0.0014 & 0.0004 \\
\hline $\mathrm{M}\left({ }^{\circ} \mathrm{Cd}\right)$ & 1189 & 899 & 688 & 1006 & 786 & 1666 \\
\hline $\mathrm{C}_{\mathrm{m}, \mathrm{w}}\left(\mathrm{g} \mathrm{m}^{-2}{ }^{\circ} \mathrm{C}^{-1} \mathrm{~d}^{-1}\right)$ & 0.6929 & 1.1498 & 0.6843 & 0.5210 & 0.4079 & 0.2539 \\
\hline$N\left(\mathrm{~kg} \mathrm{ha}^{-1}\right)$ & 67.5 & 71.6 & 97.3 & 68 & 20.9 & 19 \\
\hline \multicolumn{7}{|l|}{1998} \\
\hline$Y_{\max }\left(\mathrm{g} \mathrm{m}^{-2}\right)$ & 881.3 & 929.9 & 317.7 & 354.5 & 553.5 & 554 \\
\hline Std error & 92.3 & 26.9 & 26 & - & 42.7 & 7.5 \\
\hline $\mathrm{R}_{\mathrm{w}}\left({ }^{\circ} \mathrm{Cd}\right)^{-1}$ & 0.0036 & 0.0048 & 0.0091 & 0.0087 & 0.0055 & 0.0041 \\
\hline Std error & 0.0007 & 0.0004 & 0.004 & - & 0.0011 & 0.0005 \\
\hline $\mathrm{M}\left({ }^{\circ} \mathrm{Cd}\right)$ & 1179 & 1035 & 766 & 996 & 1127 & 1409 \\
\hline $\mathrm{C}_{\mathrm{m}, \mathrm{w}}\left(\mathrm{g} \mathrm{m}^{-2}{ }^{\circ} \mathrm{C}^{-1} \mathrm{~d}^{-1}\right)$ & 0.7931 & 1.1158 & 0.7227 & 0.7710 & 0.7610 & 0.57 \\
\hline$N\left(\mathrm{~kg} \mathrm{ha}^{-1}\right)$ & 71.8 & 73.9 & 57.7 & 58.1 & 35 & 29.6 \\
\hline
\end{tabular}

For most species, maximum dry matter (DM) production $Y_{\max }$ was obtained at final harvest. Average dry biomass over both years was highest for C. juncea and C. cajan with over $850 \mathrm{~g} \mathrm{~m}^{-2}$, followed by $A$. histrix and $S$. hamata with $450 \mathrm{~g} \mathrm{~m}^{-}$ ${ }^{2}$ and $C$. mucunoides and $M$. pruriens with between 350 and $400 \mathrm{~g} \mathrm{~m}^{-2}$ (Table 1). In terms of nitrogen accumulated by the species, differences in maximum $\mathrm{N}$ in the foliage were observed among the species. For M. pruriens, C. juncea, C. cajan and $C$. mucunoides, $\mathrm{N}$ accumulation was around $70 \mathrm{~kg} \mathrm{~N}$ ha-1, whereas for $S$. hamata and $A$. histrix only $25 \mathrm{~kg} \mathrm{~N}^{-1}$ was found.

The observed time course of plant height for the legumes species could be accurately described by a logistic function of thermal time $\left({ }^{\circ} \mathrm{Cd}\right)$ after emergence. Correlation coefficients exceed 0.96 whereas residual variance was homogeneously distributed over the fitted curves. The rate of height increase observed in the erect species $C$. juncea and $C$. cajan was high. $C$. juncea grew fast and became the tallest $\left(C_{\mathrm{m} h}=0.292 \mathrm{~cm}\left({ }^{\circ} \mathrm{Cd}\right)^{-1}\right.$, $H_{\text {max }}=285 \mathrm{~cm}$ ) (Table 2). The herbaceous species $S$. hamata and $A$. histrix showed a slower height increase $\left(0.060-0.077 \mathrm{~cm}\left({ }^{\circ} \mathrm{Cd}\right)^{-1}\right)$ with a maximum height of about $90 \mathrm{~cm}$. Mucuna pruriens, though having a faster growth rate than $S$. hamata and $A$. histrix, had a maximum height of $70 \mathrm{~cm}$. In addition the growth period for $M$. pruriens was shorter; a phenomenon which is reflected in a $M_{\mathrm{h}}$-value of about $600{ }^{\circ} \mathrm{Cd}$. C. mucunoides had the slowest growth rate, and a maximum height of $45 \mathrm{~cm}$.

An analysis which combined early relative growth of the leaves, maximum height, $\mathrm{N}$ accumulation and dry matter production of the six species is presented in figure 1. Three groups can be distinguished. The first group which comprised $C$. juncea and $C$. cajan, produced the highest biomass and a substantial amount of $\mathrm{N}$. In the second group, $M$. pruriens and $C$. mucunoides accumulated comparable amounts of $\mathrm{N}$, but biomass production was considerably lower. The third group, consisting of $S$. hamata and $A$. histrix only produced marginal amounts of biomass and N. Based on early growth characteristics, $C$. juncea, C. cajan and M. pruriens can be considered as species with a higher competitive ability than $C$. mucunoides, S. hamata and A. histrix. 


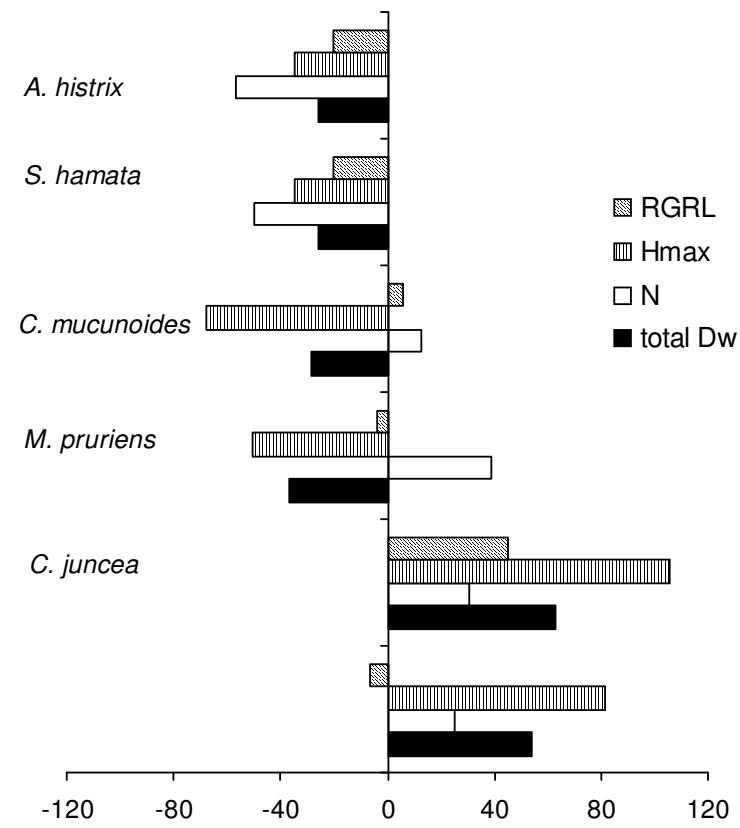

Figure 1 : Relationship between early relative growth rate of the leaves, maximum height, $\mathrm{N}$ accumulation and dry matter production of the six cover crops species. The axis represents the deviation (in \%) of the mean estimate of the different parameters. Relative growth rate of the leaves (RGRL, $0.0109 \mathrm{~m} 2 \mathrm{~m}-2\left({ }^{\circ} \mathrm{Cd}-1\right)$, maximum height (Hmax, $139 \mathrm{~cm}$ ), nitrogen (56 kg N ha-1) and total dry weight (Dw, $552 \mathrm{~g} \mathrm{~m}-2)$.

\subsection{Rice productivity}

In monoculture, V4 and WAB56-50 had similar maximum height of about $120 \mathrm{~cm}$ and similar relative height growth rate of $0.0024\left({ }^{\circ} \mathrm{Cd}\right)^{-1}$ (Table 2). The maximum rate of height increase in the inflection point reflected the differences between the two cultivars with values of $0.075 \mathrm{~cm}\left({ }^{\circ} \mathrm{Cd}\right)^{-1}$ for V4 and $0.071 \mathrm{~cm}\left({ }^{\circ} \mathrm{Cd}\right)^{-1}$ for WAB56-50. Maximum dry weight was $9 \mathrm{t} \mathrm{ha}^{-1}$ for $\mathrm{V} 4$ and $9.8 \mathrm{t} \mathrm{ha}^{-1}$ for WAB56-50.

Table 2 : Parameter values for the logistic height growth equation $\mathrm{H}=\mathrm{Hmax} /(1+\mathrm{Bh} \times \exp (-\mathrm{Rh} \times \mathrm{TSs}))$ describing plant height and height increase rate of the six cover legumes and the two rice varieties

\begin{tabular}{lcccccccc}
\hline & C. cajan & C. juncea & M. pruriens & C. mucunoides & S. hamata & A. histrix & V4 & WAB56-50 \\
\hline $\mathrm{H}_{\max }(\mathrm{cm})$ & 252 & 285 & 69 & 45 & 91 & 91 & 118 & 121 \\
Std error & 12.7 & 9.9 & 3 & 2.8 & 7.3 & 8.4 & 18 & 20 \\
$\mathrm{R}_{\mathrm{h}}\left({ }^{0} \mathrm{Cd}\right)^{-1}$ & 0.0029 & 0.0041 & 0.0052 & 0.0038 & 0.0026 & 0.0034 & 0.0024 & 0.0025 \\
$\mathrm{Std}$ error & 0.0003 & 0.0004 & 0.0011 & 0.0006 & 0.00028 & 0.00045 & 0,0007 & 0.0008 \\
$\mathrm{M}_{\mathrm{h}}\left({ }^{0} \mathrm{Cd}\right)$ & 1172 & 904 & 588 & 1082 & 1370 & 1471 & - & - \\
$\mathrm{C}_{\mathrm{m}, \mathrm{h}}\left(\mathrm{cm}{ }^{0} \mathrm{C}^{-1} \mathrm{~d}^{-1}\right)$ & 0.182 & 0.292 & 0.089 & 0.043 & 0.06 & 0.077 & 0,075 & 0,071 \\
$\mathrm{R}^{2}$ & 0.99 & 0.99 & 0.96 & 0.98 & 0.99 & 0.99 & 0,96 & 0,97 \\
\hline
\end{tabular}

$C_{m, h}$ Maximum height increase rate of the species at $R_{h}=M_{h}$

$H_{\text {max }}^{m, h}$ Maximum height

$M_{h}$ Time when species reached $50 \%$ of maximum height 
In intercropping, advancing the sowing date of legumes led to a decline in rice grain yield. The two legume species caused a significant rice grain yield reduction between 0 to 28 DARS. With V4, a yield loss of $99 \%$ at 0 DARS and $4.5 \%$ at 28 DARS was found when C. cajan was the intercrop component (Fig.2). When S. hamata was the intercrop, loss in grain yield was $52 \%$ at 0 DARS and $8 \%$ at 28 DARS. For WAB56-50, the trends were quite similar. In intercropping with $C$. cajan, $99 \%$ loss in grain yield was observed at 0 DARS and $45 \%$ if the relay crop was introduced 28 days later. In combination with S. hamata, reductions in grain yield of $53 \%$ and $6 \%$ respectively were observed at 0 and 28 DARS.
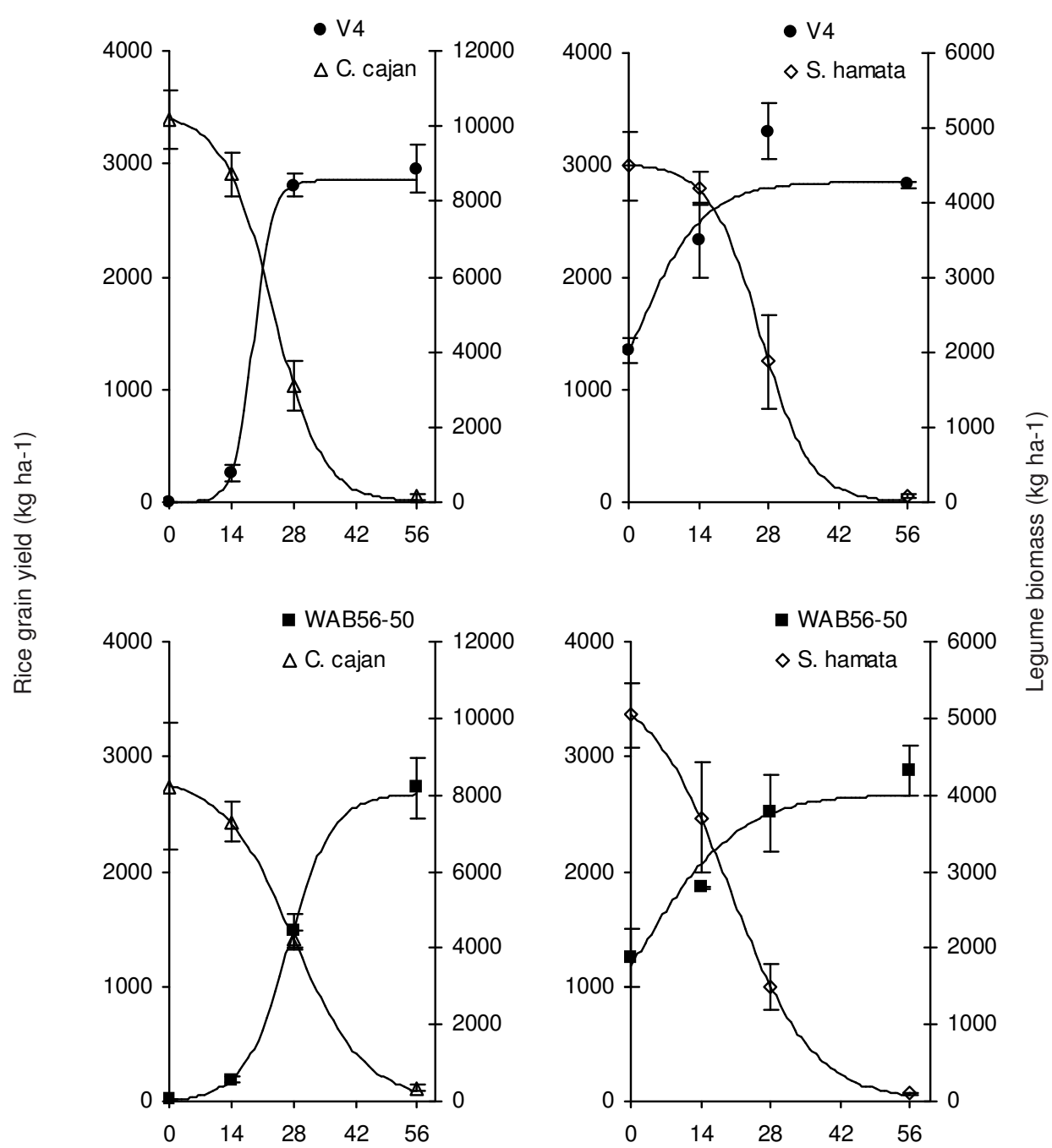

Day after rice sowing (DARS)

Figure 2 : Rice grain yield (kg ha-1) and shoot dry weight of cover crops at one week after rice harvest (kg ha-1) as a function of legume sowing date (days after rice sowing; DARS). Bars represent standard errors of the observations. 
The competition effect is also reflected in Fig. 3 where harvest index is plotted against the relative biomass of the rice crop. Only in conditions where biomass was severely reduced, harvest index (HI) dropped considerably reflecting a proportional reduction in grain yield at high levels of competition. The reductions in $\mathrm{HI}$ were observed when rice cultivars were mixed with $C$. cajan at sowing dates between 0 and 28 DARS. The less competitive S. hamata hardly affected $\mathrm{HI}$

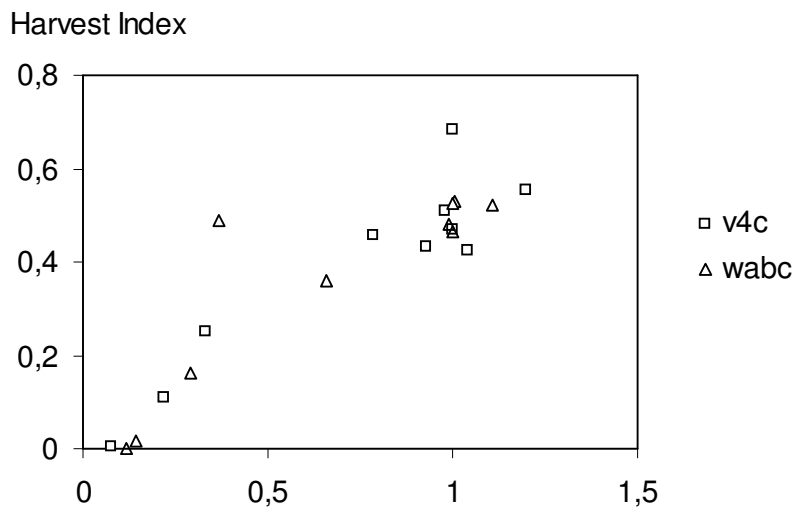

Harvest Index

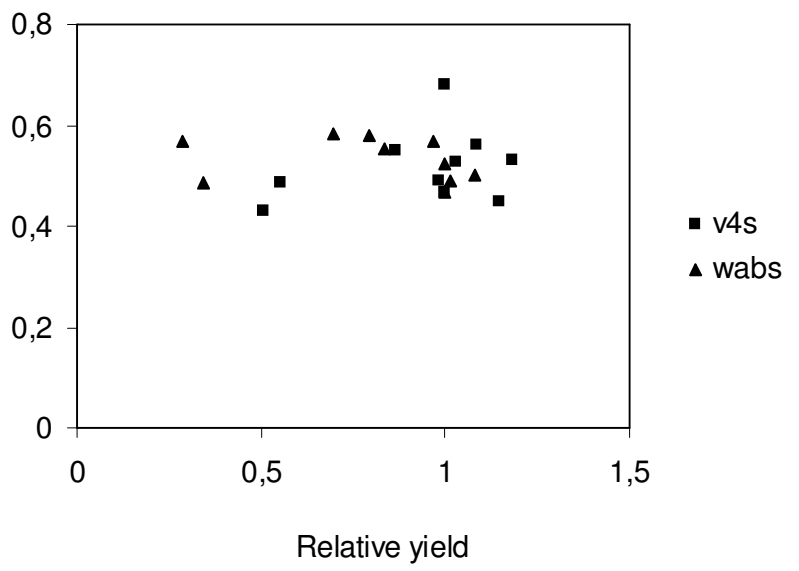

Figure 3 : Effects of the competitive legume species (C. cajan) and the non-competitive species (S. hamata) on rice harvest index $(\mathrm{HI})$ as a function of relative yield (biomass in mixture/total biomass in monoculture). ( $\square$ V4 in mixture with $\mathrm{S}$. hamata (V4S), $\triangle$ WAB56-50 in mixture with S. hamata (WABS), $\triangle$ WAB56-50 in mixture with C. cajan (WABC), $\square$ V4 in mixture with C. cajan (V4C))

\subsection{Analysis of the cropping system}

The effect of establishing the cover crops in relay with upland rice was assessed by the relationship between loss in rice grain yield and accumulated legume biomass, using equation (8). Figure 4 shows a direct relation between absolute legume biomass one week after rice harvest and relative yield loss in rice. The relationship followed an S-shape curve. With the competitive specie $C$. cajan, the two curves representing each rice cultivar initially followed the same pattern. However at early introduction dates which corresponded to the top of the curves, differences between the two curves became larger. At each sowing date of the legumes, a larger amount of biomass was produced when the legumes were combined with $\mathrm{V} 4$, at the cost of a 
comparable fraction of rice yield loss. Whereas C. cajan was able to produce around $12 \mathrm{t} \mathrm{ha}^{-1}$, and completely out-competed the rice crops, $S$. hamata produced slightly over $4 \mathrm{tha}^{-1}$ at maximum, thereby causing a rice yield reduction of about $50 \%$.

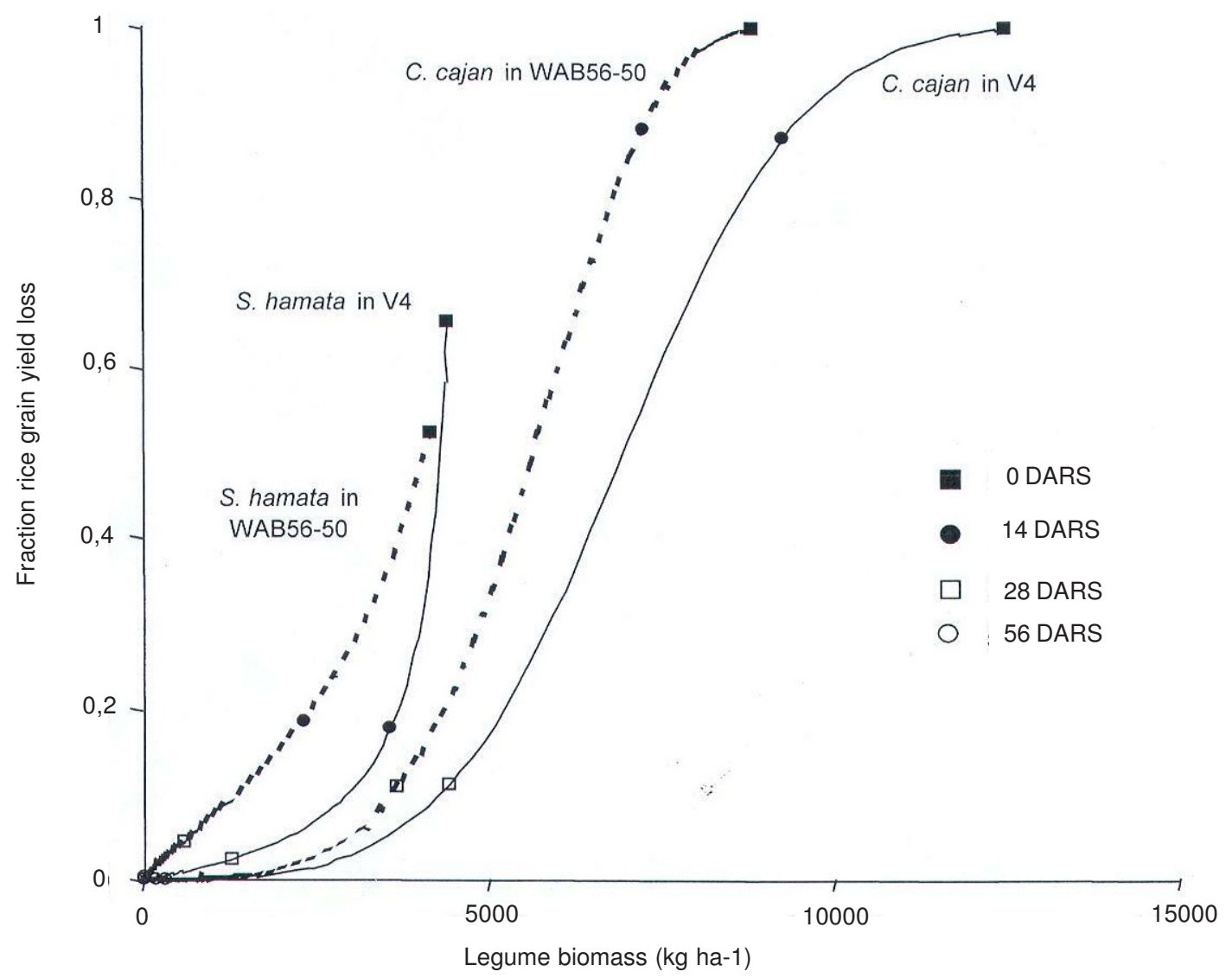

Figure 4 : Relationships between yield loss in rice grain yield and accumulated dry legume biomass at one week after rice harvest for different rice legume combinations. Markers refer to actual sowing dates of the legumes.

At late sowing periods of $S$. hamata (bottom of the curve), differences between V4 and WAB5650 were apparent. With WAB56-50, yield loss was fast, whereas only a small reduction in grain yield was observed with V4. For practical application, the lower part of the curves is most relevant as it describes the relationship between legume biomass production and rice grain yield loss at low levels of yield loss.

\section{Discussion}

The common important traits that determine competition for light between plants are inherent to the species. These traits are growth rates and the architec-ture of the canopy (Davis \& Garcia, 1983 ; Kropff \& van Laar, 1993). Relationships between these morphological traits are widely used in competition models to study the competitive strength of the species (Bastiaans et al., 1997; Kropff \& van Laar, 1993; Lindquist \& Mortenson, 1997). C. juncea, C. cajan and $M$. pruriens were found more competitive than C. mucunoides, $S$. hamata and $A$. histrix due to a combination of high initial growth rates for height and leaf area development. Additionally, the greater final height of $C$. juncea and $C$. cajan conferred higher competitiveness throughout the growing season. 
The study on rice-cover legume intercropping systems showed that rice biomass and grain yield increased with a delay of the relative sowing time of the cover legume component. For the two legume species in mixture with rice, the decrease in biomass resulting from a delay in sowing followed a logistic pattern. At late relay establishment of both legume species, a very low amount of legume biomass was produced, which could be attributed to the combined effect of a stronger competition of the rice crop and a shorter growing period of the legume species. The rice variety V4 sustained the presence of either one of the legume species and could therefore be more competitive than WAB56-50.

Cajanus cajan was found more competitive than $S$. hamata because it has a higher growth rate, a higher early leaf area expansion rate, and a faster early height growth rate. In addition, a maximum height of $252 \mathrm{~cm}$ was found for $C$. cajan, whereas $S$. hamata had $90 \mathrm{~cm}$, which is comparable to that of the rice cultivars. These characteristics allowed $C$. cajan to have a greater access to light compared to $S$. hamata, when they were grown as a relay crop in rice. Solar radiation provides the energy for the photosynthetic processes which determine productivity (Goudriaan \& van Laar, 1994). Therefore, if an intercrop component is taller and develops more leaf area at the top of the canopy with horizontal leaf orientation, it might be less depressed by the other crop (Keating \& Carberry, 1993). In this study, the introduction of the more competitive $C$. cajan led to higher amounts of biomass for comparable rice yield losses and should, therefore, be preferred.

Successful crop combinations in intercropping systems, have involved components of different durations in which the short-duration or dominant component matures before the late-maturing component (Balasubramanian \& Rao, 1988). Generally farmers favour the main crop by cropping it at an optimum density (Rao, 1986). Such combination is found in West African farming systems where, for example, cowpea and millet are sown at low density in intercropping systems with maize to minimize competition between species. Similarly in rice-cover legume systems, rice represents the important crop. Therefore, the legume component should not out compete the rice plant.

The optimum period to establish the intercrop component is a key to successful intercropping systems. In maize-Mucuna systems, 40 to 45 days between the sowing of the two species has been suggested to avoid maize yield reduction (Osei-Bonsu \& Buckles, 1993). The current study clearly suggests that in upland rice-cover legume relay systems most benefit might be expected from the use of a competitive species. A sowing time of 30 to 35 DARS was identified for intercropping $C$. cajan in upland rice. At these dates, a yield loss in rice grain of up to $5 \%$ is expected. An intercropping system involving the less competitive species $S$. hamata might be acceptable in combination with a competitive rice cultivar. This legume could be introduced as early as three to four weeks after rice sowing. Contrary to early sowing of the cover crops, late sowing had little effect on rice production. In this case, production of legume biomass was small and consequently only small amounts of nitrogen will add to the system (Akanvou, 2001). Delaying the sowing time can be considered as an important management strategy in relay cropping systems, as it reduces the competitiveness of the relayplanted species (Gilbert, 1998 ; Fischler \& Wortmann, 1999).

In West Africa savanna zones, residual soil moisture after maturity of the rice crop allows for an extended growth period of the relay crop. Such a period is important for the cover crops to increase biomass production. Therefore desirable characteristics of suitable legume species for an intercropping system, like a fast growth rate and tolerance to drought must be related to an optimum utilization of the growth period after rice harvest. In addition, the legume species should provide substantial amounts of $\mathrm{N}$ for subsequent crop (Willey et al., 1983).

\section{Conclusions}

This study indicates the wide variability in productivity and competi-tive ability of the selected legume species that might fit the upland rice system. Based on relative growth rate of the leaves, the height increase rate and total biomass, $C$. juncea, $C$. cajan and $M$. pruriens were identified as potentially competitive. Slowgrowing species such as $S$. hamata and $A$. histrix were less competitive.

Legumes characteristics and sowing dates of the legume were important factors for relayintercropping cover crops in upland rice cropping 
systems. The findings indicate that minimization of yield loss in the current rice crop is incompatible with maximization of legume biomass production due to competition between the intercrop components. Using competitive species was more beneficial, as more biomass could be obtained at comparable levels of yield loss. The outcome of selecting a specific legume species was more significant than choosing either one of the two rice cultivars. The rice grain yield loss legume biomass relationship showed that $C$. cajan was the most appropriate legume species in relay intercropping system with upland rice. A sowing time of 30 to 35 days after rice sowing was identified as optimum for intercropping $C$. cajan in upland rice.

\section{References}

Akanvou R.K., 2001. Quantitative understanding of the performance of upland rice-cover legume cropping systems in West Africa. PhD. Wageningen University, The Netherlands. 149 pp.

Anderson J.M., \& Ingram J.S.I., 1993. Tropical soil biology and fertility. A handbook of methods (second edition). CAB International, Wallingford, UK, $221 \mathrm{pp}$.

Balasubramanian V., \& Rao G.D., 1988. Intercropping effects on yield components of dryland sorghum, pigeon pea and mung bean. Trop. Agric. (Trinidad) 65: 145-149.

Becker M., \& Johnson D.E., 1998. Legumes as dry season fallow in upland rice-based systems of West Africa. Biol. Fertil. Soils. 27: 358-367.

Bastiaans L., Kropff M.J., Kempuchetty N., Rajan A., \& Migo T.R., 1997. Can simulation models help design rice cultivars that are more competitive against weeds? Field Crops Res. 51: 101-111.

Davis J.H.C., \& Garcia S., 1983. Competitive ability and growth habit of intermediate beans and maize for intercropping. Field Crops Res. 6: 59-75.

Dingkuhn, M., Johnson D.E., Sow A.., \& Audebert A.Y., 1999. Relationships between upland rice canopy characteristics and weed competitiveness. Field Crops Res. 61: 79-95.

Fischler M., \& Wortmann C.S., 1999. Green manure research in eastern Uganda: Agronomic performance and farmers' perceptions. Agrof. Sys. 47: 123-138.
Genstat 5. Release 4.1. 1998. Fourth edition Lawes Agricultural trust. IACR-Rothamsted, UK.

Gilbert R., 1998. Undersowing green manures for soil fertility enhancement in the maize-based cropping systems in Malawi. In: Waddigton, S.R., Murwira, H.K., Kumwenda, J.D.T., Hikwa D., \& F. Tagwira. Eds. Soil fertility research for maizebased cropping systems in Malawi and Zimbabwe. SoilFertNet/CYMMIT-Zimbabwe, Harare, Zimbabwe. pp. 73-80.

Goudriaan J. \& Van Laar H.H., 1994. Modelling potential crop processes. Textbook with Exercices. Kluwer Academic Publishers, Dordrecht, the Netherlands. $238 \mathrm{pp}$.

Kropff J.M. \& Van Laar H.H., 1993. Modelling Cropweed interactions. Cab International Publishers, Wallingford, UK. 267 pp.

Lindquist J.L., \& Mortenson D.A., 1997. A simulation approach to identifying the mechanism of maize tolerance to velvet leaf competition to light. In: The 1997 Brighton Crop Protection Conference-Weeds, Brighton, UK. pp. 503-508.

Keating B.A., \& Carberry P.S., 1993. Resource capture and use in intercropping: Solar radiation. Field Crops Res. 34: 273-301.

Midmore D.J., 1993. Agronomic modification of resource use and intercrop productivity. Field Crop Res. 34: 357-380.

Morris R.A., Siri-Udompas C., \& Centeno H.S., 1990. Effects of crop proportion on intercropped upland rice and cowpea. 1. Grain yield. Field Crops Res. 24: 33-49.

Mulongoy K., \& Akobundo I.O., 1990. Agronomic and economic benefits of nitrogen contributed by legumes in live-mulch and alley cropping systems. In: Gresshoff P.M., Roths L.R., Stacey G., \& Newton W.E., Eds. Nitrogen fixation: Achievements and objective. Chapman and Hall, New York. pp. 625-632.

Osei-Bonsu P., \& Buckles D., 1993. Controlling weeds improving soil fertility through the use of cover crops: Experiments with Mucuna spp in Benin and Ghana. West African Farming Systems Research Network Bulletin 14: 2-7.

Rao M.R., 1986. Cereals in multiple cropping. In: Francis, C.A., Eds. Multiple cropping systems. MacMillan, New York, pp. 96-132. 
Terry E.R., Malton P.J, Adesina A.A. 1995. Enhancing productivity in the agricultural sector: The case of rice in sub-Saharan Africa. Paper presented at the UNDP Asia-Africa Forum, 12-16 December 1994, Bandung, Indonesia.
Willey R.W., Natarajan M., Reddy M.S., Rao M.R., Nambiar P.T.C., Kannaiyan J., \& Batnagar V.S., 1983. Intercropping studies with annual crops. In: Better crops for food. Ciba Symposium No. 97, Pitman, London. pp. 83-100. 